\title{
$\begin{array}{lllllllll}\mathbf{D} & \mathbf{O} & \mathbf{K} & \mathbf{U} & \mathbf{M} & \mathbf{E} & \mathbf{N} & \mathbf{T} & \mathbf{Y}\end{array}$
}

\section{SŁUŻBA ŻYCIU \\ PODSTAWOWYM ZADANIEM RODZINY}

\section{PIUS XI - "CASTI CONNUBII" 1}

Wspomniec musimy, Czcigodni Bracia, o jeszcze innej zbrodni, zagrazającej zyciu dziecka, które się znajduje w łonie matk1. W tej sprawie jedni pragna decyzje uzależnic od woli ojca lub matki, inni znów chcą na ten zabieg wórczas tylko pozwolić, jeśl1 zachodzą wyjątkowo ważne powody, które nazywają "wskazaniem" lekarskim, społecznym czy eugenicznym. Wszyscy domagaja sie, aby karne ustary państwowe, ścigające zamach na zycie dziecka wonie matki, uznały ich wskazania/nie wszyscy bronia tych samych/i nie ścigały karami. Zada się nawet tu i ómdzie, by wladze publiczne wzięly woje ręce wykonanie tej śmiercionośnej operacj, co, Jak wszystkim wiadomo, gdzieniegdzie juz sie niestety dzieje.

W sprawle "wskazań lekarskich lub terapeutycznych" - by uzyć tych okrésleń - wyraztliśmy juz, Czcigoani Bracia, swoje glębokie współczucle dla takiej matki, której w spełnienłu obowiazku naturalnego zagrazaja choroby, a nawet śmierć. Jakiz jednak kiedykolwiek moźna przytoozyć powód dla usprawiedliwlenia zamierzonego zabójatwa niewinnogo dziecka? A przeciez o to tutaj chodzi. I czy ono godzi

Wyboru 1 opracowanta dokumentów dokonal ks. Stanłsław Longosz.

1 AAS 22/1930/562-565, trum.ks.bp S. Okoniowski /Encyklika o malżeństwie chrzécijańskim "Casti connubi1" z dnia 31 grudnia 1930r., Kraków 1931, 33-37\% Wcześriejsza encyklika o mazzeństwie "Arcanum divinae sapientiae" Leona XIII z 10 II 1880 nie porusza problemu przerywanta c1azy. 
w życie matki, czy w źycie dziecka, zawsze sprzeciwia się przykazaniu Bożenu 1 głosowi przyrodzoneıu: "Nie zabijaj" dziecka tak samo jest święte, jak życie matki. Stłumié go nikt, nawet państwo, nigdy nie będzie miało prawa. Bardzo niedorzecznie przywodzi się przeciw tym niewinnym istotom prawo miecza, gdyz ono dotyczy jedynie winnych. Nie wchodzi tu takze w gr zasada godziwej i krwawej obrony przeciw napastnikowi /któż bowiem mógłby takie niewinne maleństwo nazwać napastnikiem?/. Nie ma teź źadnego tak zwanego prawa "bezwzględnej konieczności", któreby mogło usprawledliwic zabicle niewinnego dziecka. Na pochwałe zasługuja zatem owi sumienni i doświadczeni lekarze, którzy staraja się zachować 1 obronić zycio matki i zycie dziecka. Niegodnymi natomiast okazaliby się szlachetnego miana 1 lekarskiego tytułu ci, którzy by ze względów leczniczych lub przez niewłaściwe współczucie nastawali na zycie matki lub produ.

Wywody nasze zgadzaja sie całkowicie z ostrymi wyrzutami wypowiedzianymi ongiś przez Biskupa Hippony przec1w małzonkom, kt6́rzy wystrzegaja sie usilnie potomstwa, a gdy $1 \mathrm{~m}$ sie to nie uda, zbrodniczo je niszcza. Pisze bowiem: "To rozpustne okrucieństwo,albo raczej ta okrutna rozpusta, zapędza się nieraz tak daleko, ze uzywa trucizn przeciw zapłodnieniu, a gdy te zawodza, niweczy innym1 środkami płód poczęty w łonie 1 spędza go. Tacy ludzle wolą, by potomstwo zginęło zanim jeszcze zaczęło żyć, lub, gdy się juz znalazło łonie, wola je zniszczyć, niż pozwolićmu ujrzeć śriatzo. Jeśli oboje sa takimi, nie moźna ich naprawdę nazywać małzonkami, a jeślı od początku takimi byli, 1ch mspółzycie nie było małżéstwem,

2 Por. Declaratio S.Officii quoad operationem chirurgicam, quae craniotomia dicitur /28 V 1884/, ASS 17/1884/555-556; Epistola S.Officit ad Archiepiscopum Cameracensem de operatione chirurgica, quae directe occidat foetum vel matrem gestantem, ASS 22/1889-1890/748: "... Eminentissimi ac Reverendissimi Patres Cardinales una mecum Inquisitores, feria IV die 14 August1 1889 respondendum mandaverunt: In scholis catholicis tuto doceri non posse licitam esse operationem chirurgicam quam craniotomiam appellant, sicut declaratum fuit die 28 Mail 1884 et quamcumque chirurgicam operationem directe occisivam foetus vel matris gestantis". 
lecz nierządem. Jeśli zaś nie oboje są takimi, powiem wyraźnie: "albo ona jest nałoznica męza, albo on cudzołoży ze swoją zonąn ${ }^{3}$.

Volno natomiast 1 powinno się mieć na wgleqdzie to wszystko, co przemawia za wskazaniami społecznymi 1 eugentcznymi, byleby sie to ostaggało środkaini dozwolonymi, uczciwyint 1 w słusznych graricach. Chcieć natomiast przez zabijanie niewinnych zaradzać owym koniecznościom, na których owe wskazania się oplerają, byłoby rzeczą niemądrą 1 przeciwnaz przykazan1u Bozemu, wypowiedzianemu w słowach Apostoła: "Nie wolno czynić rzeczy złych, aby osiągnąé dobre"izz 3, $8 /$.

W końcu rządy 1 ciała ustawodawcze nie powinny o tym zapominać,ze jest to ich obowizzkiem stancé przy pomocy odpowiednich ustaw 1 kar w obronie życia niewinnych. Obowizzek ten jest tym pilniejszy, im mniejsza istnieje mozliwośc samoobrony u tych, których źycie jest zagrozone 1 zwalczane. Należy do nich zallczyć przede wszystkim dzieci w łonle matk1. Jeśli zatem wadze państwowe nie tylko nie bronia owych maleństw, lecz swoim ustawodawstwem 1 zarzadzeniami na tego rodzaju zabiegi się zgadzają 1 owe maleństwa nydają w ten sposób na pewną śmlerć ręce lekarzy 1 innych osób, to niech pamiętają o tym, ze Bóg jest sędzią 1 mścicielem krwi niewinnej, wołajacej z ziemi do nieba/Rdz $4,10 /$.

\section{PIUS XII - PRZEMÓWIENIA}

\section{Do połoznych}

Kazda 1stota ludzka, w tym również dziecko w lonle matki, otrzymuje prawo do zycia bezpośrednio od Boga, a nie od rodziców, czy od Jakiejśs społeczności lub zwierzchności ludzkiej. Nie ma więc zadnego człowieka, żadnej zwierzchności ludzkiej, zadnej wiedzy, zadnego "wskazania" lekarskiego, eugenioznego, socjalnego, ekonomicznego 1 moralnego, które by mogło usprawiedliwić lub dostarczyć waznego tytułu prawnego do swiadomego bezpośredniego dysponowania nie-

3 De nuptils et concupiscentia I 15, PL 44,423-424. 
Winnym źyciem ludzkim, Inaczej mówiąc, dysponowania czy to jako celu, czy jako środka do osiągnięcia innego celu, który sam sobie jest niedozwolony. Tak np. ocalenie zycia matk1, jest znakomitym celem, ale świadome zabicie dziecka jako środka do osiagnięcia tego celu, jest niedozwolone. Nie moźna w żaden sposób usprawiedliwiac praktykowanego od kilku lat bezpośredniego niszczenia tzw. "życia bez znaczenia", narodzonego lub jeszcze nienarodzonego. Dlatego też, po rozpowszechnientu się tej praktyk1, Kościóx wielokrotnie wyjaśniał, ze sprzeciwia sie ono formalnie prawu naturalnemu 1 pozytywnemu prawu Bozemu, ze nie wolno zabijać nawet tych niewinnych, którzy ze względu na ułomności duchowe lub psychiczne nie tylko są nieuzyteczni dla narodu, ale stanowia dia niego ciezar /Decretum S.officil 2 XII 1940/ ... Zycie niewinnego jest nietykalne, a jakikolwiek bezpośredni zamach lub agresja przeciw niemu jest pogwałcentem jednego z fundamentalnych praw, bez których niemożliwe jest bezpieczne współzycie ludzi.

\section{Do członków Stowarzyszenia "Fronte della Famiglia"}

W centrum naszego nauczania ukazuje się małżeństwo jako instytucja do służenia życiu. W ścisłym zwiazku z tym principium przedstawiamy nlezmienna nauke Kościoła, że jednz z fundanentalnych tez nie tylko moralności malżeńskiej, ale równiez moralności socjalnej w ogóle, jest załoźenle, iż bezpośredni zamach na niewinne źycie ludzkie, będący środkiem do celu - aby ratować inne życio - jest niedozwolony. Niewinne zycie ludzkie, w jakimkolwiek by się znajdowało stanie, winno być ratowane przez świadome działanie juz od pierwszego momentu swego istnienia. Jest to fundamentalne prawo osoby ludzkiej o znaczeniu ogólnym pojęciu życia chrześcijańskiego. Ma ono znaczenie zarówno dla życia ukrytego jeszcze w łonie matki jak 1 rozwiniętego już poza nią, tak przeciw bezpośredniemu spędzaniu płodu jak i przeciw bezpośredniemu zabijaniu dziecka przed,podczas czy po urodzeniu. Jeśli dla prawa świeckiego lub kościelnego i dla pewnych konsekwencji cywilnych lub karnych może mieć znaczenie rozróżnianie między tymi różnymi etapami rozwoju życ1a narodzonego albo jeszcze nienarodzonego, to w prawie moralnym we wszystkich tych wypadkach chodzić będzie o ciężki i niedopuszczal ny zamach na nietykalne zycie ludzkie. 
Zasada ta ma znaczenle zarówno dla życia dziecka jak i dla zycia matki. Nigdy 1 w żadnym wypadku Kościół nie uczył, że życie dzlecka winno być stawiane wyżej od zycia matki. Błędem jest stawianie pytania z taka alternatywa: zycie dziecka albo zycie matk1. Ani zycle dzlecka, ani zycie matki, nie moga być poddawane aktowi bezpośredniego niszczenia. Dla jednej jak $i$ dla drugiej strony istnieje tylko jedno wymaganie: uczynić wsyystko, by ocalić źycie obydwo.jga - matki i dziecka ${ }^{4}$.

\section{JAN XXIII - "MATER ET MAGISTRA"}

W tej sprawie uroczyście ogłaszamy, że życie ludzkie powinno być przekazywane poprzez rodzinę założona przez małzeństwo, jedno i nierozerwalne, podniesione dla chrześcijan do godności sakramentu. Przekazymanie zycia ludzkiego jest powierzone przez nature aktowi osobowemu 1 świadomemu 1 jako takie jest poddane najmędrszym prawom Bożym, prawom niezłomnym 1 niezmiennym, które wszyscy powinni przyjąć $i$ zachować. Nie można więc używać środków ani iść za metodami, które moga być dozwolone przekazywaniu źycia roślin 1 zwierząt.

N1echże więc wszyscy uwaźają życie ludzkie za święte, a to dlatego, ze od samego początku mymaga działania Boga Stwórcy. Ten więc, kto odstępuje od tych Bozych praw, nie tylko uwacza Jego Majestatow1 1 okrywa hańba siebie samego i rodzaj ludzki, lecz także podwaźa u samych podstaw siłe społeczności, do której należy 5 .

IV. SOBOH WATYKANSKI II - "GAUDIUM ET SPES"

Sobór zdaje sobie sprawę z tego, że małżonkowie mogą w układaniu harmonijnie pożycia małżeńskiego doznać trudności skutkiem

4 Tekst pierwszy /29 X 1951/, AAS 43/1951/838-839; tekst drugi /26 XI 1951/, AAS 43/1951/857-858. Ubydwa z włoskiego tłum. ks.S. Longosz.

5 Pars III, AAS 53/1961/447, polski przekład wg "Encykliki"/Jan XXIII, Paweł VI, Jan Paweł II/, Warszawa 1981, 37 . 
niektórych dzisiejşych warunków 1 znajdować sie n takiej sytuacji, - której nie można, przynajmniej do czasu, pomnazac liczby potomstwa, 1 niełatwo jest podtrzymywać wierną miłośc 1 pełną rspólnotę zycia. Gdzle zrywa się intyme pozycie małzeńskie, tam nierzadko wiernośc może być mystawiona na próbę, a dobro potomstwa zagrozone. Wtedy bowiem grozi niebezpieczeństwo zarówno wychowaniu dzieci, jak 1 zdecydowanej woli przyjecia dalszego potomstwa.

Są tacy, którzy ośmielają się rozwiazzywać te problemy nieuczciwie; co więcej, nie wzdragają się przed zabójstwem; Kośctół jednak przypomina, ze nie moze byé rzeczywistej sprzeczności między boskimi prawami dotyczącymi z jednej strony przekazywania zycia, a z drugiej plelęgnowania prawdziwej miłośc1 małzeńskiej.

Bóg bowiem, Pan życia, powierzył ludziom wzniosła posługę strzezenia zycia, którą człowiek powinien wypełniać w sposób godny siebie. Nalezy więc z najwieksza troska ochraniać zycie od samego jego poczęcia; spędzanie płodu jak 1 dzieciobójstwo są okropnymi przestępstwami. Zycie płciowe człowieka 1 zdolnośc rozrodcza ludzi dziwnie góruja nad tym wszystkim, co znajduje sie na nizszych szczeblach zycia; z tego też powodu należy odnosić się z wielkim szacunkiem do aktów właściwych pożyciu małzeńskiemu spełnianych w sposób odpowiadający prawdziwej godności ludzkiej. Kiedy więc chodzi o pogodzente miłośc1 małzeńskiej z odpowiedzialnym przekazywaniem zycia, wórczas moralny charakter sposobu postępowania nie zależy myłącznie od samej szczerej intencji i oceny motywów, lecz musi być określony w świetle obiektywnych kryteriów, urzględniających naturę osoby ludzkiej 1 jej czynów, które to kryteria kontekście prawdziwej miłości strzega pełnego sensu wzajemnego oddawanta się sobie 1 człowieczego przekazymania zycia; a to jest niemozliwe bez kultywowania szczerym sercem cnoty czystości małzeńskiej. Synom Kościoła, wspartym na tych zasadach, nie wolno przy regulowaniu urodzeń schodzié na drogi, które Urząd Nauczyoielski Kościola przy tłumaczeniu prawa Bożego odrzuca. Niech zaś wszyscy wiedzą, że zycie ludzkle 1 zadanie przekazywania go nie ograniczaja się tylko do perspektyw doczesności, $i$ nie moga tylkow niej samej znajdować swego mymlaru i zrozumienia, lecz maja zarsze odniesiente do wiecznego przeznaczénia ludzkiego ${ }^{6}$.

6 AAS 58/1966/ 1072-1073, przekład polski wg "Sobór Watykarsk1 II. 
v. PAWEL VI - "HUMANAE VItaE"

W oparciu o te podstawowe zasady ludzkiej 1 chrześcijańskiej nauki o małzeństwie czujemy sie w obowiazku raz jeszcze ó́wiadczyé, te nalezy bezwarunkowo odrzucic - jako moralnie niedopuszczalny spośbb ograniczania 1lości potomstwa - bezpośrednie naruszanie rozpoczętego juz procesu zycia, a zwłaszcza bezpośrednie przerymanie clazzy, choćby dokonywane ze względ6w leczniczych ${ }^{7}$.

Swięta Kongregacja do Spraw Wiary

VI. DEKLARACJA O PRZERYWANIU CIÄZY 8

1. Problem przerymania clazy 1 liberalizacj1 prawa tym zakresie stał się niemal wszędzie przedmiotem ostrych dyskusj1. Miazyby one mniejsze znaczenie, gdyby nie chodz1ło o sprawe zycia ludzk1ego, które jako plerwsze 1 podstawowe dobro nalezy bezwzlędnie strzec 1 rozmijac. Jest to oczymiste dla kazdego, chociaz wielu stara sie szukać powodów, azeby wbrow oczywistości nawet przerywanie ciazy mogło słuźý temu celowi. Jest rzecza dz1mna, ze gdy z jednej strony spostrzegamy nasilente sprzeciwu wobec kary smierci 1 wszelkiej postaci wojny, zauwaza sie, ze przerywanie ciązy zyskuje coraz bardz1ej aprobate prawna czysto bezwzględna, czy tez ograntczona pewnyml grantcam1, choć są luźno traktowane. Kościól nie moze pominąć milczeniem tego problemu, poniewaz jasno zdaje sobie sprare z tego, ze do jego obowiazzkó nalezy obrona człowieka przed tym wszystkim, co mogłoby go zntszczyé lub pozbawié godnośc1. A poniewaź Syn Bozy stał sie człowiekiem, dlatego kazdy jest juz Jego bratem ze względu na wspólne człowieczeństwo 1 każdy jest powołany do tego, aby stać 81 e chrześcijaninem dla otrzymania od Niego zbawienia.

Konstytucje, dekrety, deklaracjen, Poznań 1968, 911-913.

7 Paulus VI, Humanae vitae 14/25 VII 1968/, AAS 60/1968/490, przeklad polski $\mathbf{m g}$ "Encyklik1", dz.cyt. 149 .

8 Podajemy jej triy pierwsze rozdziały/nr 1-13/, zawierajace pozytywny wykład nauk 1 chrzescijańskiej, pomijamy natomiast odpowiedzi na zarzuty, AAS 66/1974/730-739, przekład polsk1 wg "Specjalistycz- 
2. Wielu krajach madze publiczne, które przeciwstawiaja się usankcjonowantu przez prawo dopuszczalności przerywanta cizzy, są obiektem gwałtownych nacisków, aby dały się do tego nakłonic. Mów1 s1ę, ze nie naruszałoby to niozyjego sumtenta, ponieważ kazdemu pozostawiałoby sie swobodę pójácia za własnym zdaniem, a takze utrudniałoby narzucanie komuś wasnego zdania. Zada sie "pluralizmu etycznego" Jako naturalnej konsekwencj1 "pluralizmu ideologicznego". Tymczasem chodzl o rzeczy, które bardzo się rózria między sobą. Działania bowiem dosiegaja dobra innych szybciej, niz czyste opinio. Nikomu przy tym pod zadnym pozorem nie wolno powotywac sie na wolnośc opin11, gdy zostają naruszone prawa druglch, zwlaszcza prawo do zycia.

3. Hoznl chrześcijanie śrieccy, zwlaszcza lekarze, politycy 1 wybitne osobistoścl stanowczo przecinstawiali sle świadomie prowadzonej kampanil z owa wolnościa opin11; jak równiez storarzyszenia ojcó 1 matek. Przede mszystkim zá́ biekup1 zebran1 na konferencjach episkopatów, Jak równiez poszczególni biskupi we własnym imientu uznall za stosowne pouczyć wiernych bez zadnef dwuznacznośc1 o przokazanej nauce Koscioła9. Te dokumenty, uderzająco zgodne ze sobą, jasno podkreślaja to, co nalezy się zyciu ludzkiemu stosownie do wymagar natury człowieka 1 nauki chrześcifaŕskiej. Niemniej, zdarza się, ze spotykaja się one nierzadko z pewnaz rezerwa a nawet całkowitą dezaprobatą.

4. Swleta Kongregacja do Spraw Wiary, stosownie do powierzonego soble obowlazzku rozszerzanta a takze strzezenia wiary 1 obyczajów Kościele powszechnym ${ }^{10}$, postanowiła przypomnié wszystkim

ne aspekty problemu przerywanta ciązy. Akta ogólnopolskiej sesj1 naukowej lekarzy i teologów 8-9 II 1975, Kraków 1975, 148-155.

$\theta$ Por. myporiedzi biskupór na ten temat, w: G.Caprile, "Noñ uco1dere" Il Mag1stero della Chiesa eul1' aborto, pars II, Roma 1973. $47-300$.

10 Por. Regimint Ecclesiae universae III, 1,29 131 , AAS 59/1967/ 897: "Swieta kongregacja do sprar miary ma za zadanie atrzec nauk1 wiary 1 obyozajow $\nabla$ cułym swiecle katolick1m ... Do niej naleza wszystkie kwestie, które dotycza nauki wiary 1 obyczaJów, albo wiąza sie z sama wiarą". 
chrześc1janom głóme zasady tej nauk1. W ten sposób, odzwierciedlając jednośc Kościoła autorytetem Stolicy śr., chce umocnic to, co juz pomyśnie w tej spramie uczynili biskupi. Ma tez nadzieje, ze wszyscy wiern1, nie wyłączając nawet tych, którzy zachwiani zosta11 tą róznica zdań 1 nowymi mniemaniami, wyraźnie zrozumieja, ze tu nie chodz1 o opinie, którą się przeciwstawia innym opintom, lecz o przekazanie stałej nauki najwyzszego Urzęu Nauczycielsk1ego, ktory wykłada normy postepowania w śmietle wiary. Jasną więc jest rzeczą, ze ta Deklaracja jest powaznym zobowiazaniem dla sumień wiernych. Niech Bóg sprawi, lzby przez nią takze byli oślecent wszyscy Inni ludzle na ómiecte, którzy szczerym sercem pragną "czynić praw$\mathrm{de}^{n} / \mathrm{J} 3,21 /$.

5. Smierci Bóg nie uczynit i nie cieszy się ze zguby zyjących"/Mdr 1,13/. Prawda Jest nlewątpliwie, ze Bóg stworzyl lstoty zyjace, które trwaja przez pewien tylko czas 1 ze nie mozna usunác bmiercl ze śriata lstot cielesnych. Zycio zas jest tym; co jest przede wszystkim zamierzone, wszystkie rzeczy widzialnym świecie utworzone są ze względu na człowieka, który jęt obrazem Boga 1 punktem kulminacyjnym stworzenia /Rdz 1,26-28/. W porzadku rzeczy ludzkich "... śmierć weszla na świat przez zawióc szatana" Mdr 2,24/. Wprowadzona przez grzech pozostaje z nim związana - jest zaróno jego znakiem jak 1 nastepstwem. Nigdy nie będz1e mogła Jednak zatryumfowac. Chrystus Pan bowiem, potwierdzajac prawde zmartwychwstania, ogzasza w Ewangeli1, ze Bóg nie jest Bogiem umarłych lecz zywych Mt 22,32/ oraz, ze śmieré tak jak 1 grzech będzie przezwyclęzona przez zmartwychwstante Chrystusie/1 Kor 15,20-27/. Stąd tez uwaza sie, ze zycie ludzkie nawet na ziemi jest bezcenne. Zycie to, tchniete przez Stworzyciela, przez Niego jest odnawiane /Rdz 2,7; Mdr 15,11/ 1 pozostaje pod Bozą opleką: krem ludzka woła do Niego /Rdz 4,10/. Zaząa On tez zdania z niego rachunku, bo "czlowiek został stworzony na wyobrazente Boga"/Rdz 9,5-6/. "Nie będziesz zabijałn $N$ J 20,13/: to jest nakaz Bozy. Zycie wprawdz1e jest darem, ale 1 jednocześnte jest zadaniem: nie tylko bowiem otrzymuje - 1e je jako "talent" Mt 25,14-30/, ale ponadto trzeba je ubogacló. Aby ono zaowocowało, wiele stol przed człowiekiem zadan do wypeznienia, od których nie moze sie on uchylic. Chrześcijanin rozumie to głęboko, zwaszcza gdy uśwladomi sobie, ze zycie wieczne zalezy od 
tego, czego on sam - wspomozony łaską Boza - - ziemskim zyciu wykona.

6. Tradycja Kościoła zawsze nauczała, ze zycie powinno byé otoczone opieka 1 powinno mu się sprzyjac, tak na początku jak 1 różnych okresach jego rozwoju ${ }^{11}$. Dlatego Koścíł od najdawniejszych czasów, przeciwstawiając się obyczajom Groków 1 Azymian, z naciskiem twierdz1ł, te chrześcijańskie obyczaje bardzo się róznia pod tym względem.

W dziele zatytułowanym "D1dache" stwierdza sie to jasno: "N1e będziesz zabijał płodu, przerywając ciazze, ant nie zabijesz narodzonego dzlecięcian'12. Atenagoras podkreśla, ze kobiety, kt6re posługują sie środkami medycznymi celen usuntęcia płodu, umażane są przez chrześcijan za winne zabójstwa. Potępia on zabójczynie dziec1, nawet nie narodzonych, pontewaz juz saz przedmiotem trosk1 Bozej 13. Być moze Tertulian nie zawsze jednoznacznie o tym pisze, niemniej jednak jasno stawia te 1stotna zasadę: "Uniemozlivianie porodzenia jest przyspieszaniem zab́jstwa. I nie ma rónticy, czy któs úsmierca zycie juz narodzone, czy dopiero rodzace sie. Człowiekiem jest 1 ten, kto ma nim byc. Przeciez wszelki owoc istnieje juz nasieniun 14 .

11 Autorzy natchnieni nie prowadza dysput filozoficznych o animacj1 płodu, lecz mówia o okresie zycia, który poprzedza narodzenie, a o który stara się Bóg. Bóg stwarza 1 kształtuje człowieka, wykonując go niejako własnoręcznie. Wydaje sie, ze tego rodzaju temat po raz pierwszy podejmuje Jeremiasz 1,5 ; znajduja sie - nim wzmianki 1 wielu Innych miejscach Pisma rqiętego. Por. Iz 49,1; Iz 49,15, 46,3; Job 10,8-12; Ps 22, 10; 71,6; 139, 13 . W Ewangel11 św.Lukasza /1,44/ czytamy: "Skoro głos Trego pozdrowienia zabrzmiał moich uszaoh, poruszyło się z radości dzieclatko moim lonle".

12 Didache 5,2, SCh 248,168, por. POK 1,30; Epistola Barnabae SCh 172, 202, POK 1,89.

13 Athenagoras, Legatio pro christiants 35,PG 6,970: "Jak mozemy zabíc ozłowieka, skoro uczymy, ze koblety, które uźyøają środkóì medycznych do spedzenia płodu, sa morderczyniami 1 zdadzaz z tego sprawe przed Bogiem? Nie moźna równocześnie sądzić, ze płód wonie matki jest istotą zyrą, o którą się troszczy sam Bóg, a z arugiej strony zabijac to co zostału wydane na śriat. Nie mozna tez porzucäć niemowlęcia, pónieważ ci, którzy je porzucają sie dzièciobójcami"; por. Epistola ad Diognetum 5,6, SCh 33,62: "Dzieci rodza, a płodu nie porzucają".

14 Apologeticum 9,8, $\mathrm{CCL}^{-1,103: ~ " H o m i c i d i ~ r e s t i n a t i o ~ e s t ~ p r o h i b e r o ~}$ nasci, nec refert, natam quis eripiat animam an nascentem dis- 
7. T clągu wieków święci Ojcowie Kościoła 1 jego Pasterze oraz Doktorzy nauczali tego samego 1 nawet różica zdá́ co do momentu, w kórym dusza laczy się z ciałern, nigdy nie zachwiala przekonania - nlegodziwości przerywanla ciazy. Prawda jest istotnie, ze wrednlowieczu wskutek ogólnego przeświadczenia, ze dusza pojawia się m płodzle dopiero po kilku tygodniach, czyniono róznlce między oceną takiego grzechu 1 cięzaru sankcj1 karnych. Stąd poważni nawet autorzy pojmowali dośc lagodne rozwizania przypadkow zwazanych z plerwszym okresem ciazy, odrzucali je jednak, gdy chodz1ło odalszy okres. Nigdy przy tym nie zaprzeczali twierdzeniu, ze przerywanie oiazy nawet pierwszych dniach jest obiektywnie grzechom cięzim 1 rzeczywiście potępienie takiego czynu było jednomyślne. Waysy zgadzali sie co do takiego potępienia. Z wielu dokumentóv, istniejacych tej kwest11, wystarczy wspomnié chó́by niektóre.

Plerwszy Synod Moguncki z 847 roprzyjmuje kary nałoźoñe $3 a$ przerywante ciazzy przez poprzednie Synody 1 uznaje, ze najsurowsza pokuta powinna byó nałozona na kobiety, które "płód swój niszcza albo które powoduja usuntecie ciązy z łonant5.

W Dekrecie Gracjana cytowane sa słowa papieza Sterana V: "Kto by zgładziz zycie poczęte, jest mordercą"16.

Sw.Tomasz, Doktor powszechny Xościoła naucza, ze zniszczonie płodu jest grzechem cięzkim, przectwnym prawu natury ${ }^{17}$.

turbet. Homo ost et qui est futurus: otiam eructus omnis iam in semine ost"; por. POK 20,42.

15 Concil1um Moguntinum can.21, Mans1 14,909; por. Conciliun E11ber1tanum can.63, Mansi 2,16; Concilium Ancyranum can.21, Mansi 2,519; Gregorius III papa, Iud1c1a congrua poent tentibus can.17, Mansi 12,292/o pokucie dia koblet dopuszczających sie przerypania ciazy/.

16 Decretum Gratian1, Concordia discordantium canonum, C.2, can.20, 9-5. W okresie średniowlecza zaś odwolymano sie do autorytetu 6. Augustyna, kt6ry w dziele "De nuptis ot oncupiscent1a oap.15 tak pisat: wilekiody tak daleko posuwa sie ta rozwlazza okrutnós albo rozpusta okrutna, zo nawet wyszukuje sle trúcizñ prociw płodnośc1, a gdyby nie dzlałala, pragnąc dla siwego ptomka raczej śmierci niz tycia na wszelk1 sposób uiszczy poczęty piód * Ionte 1 myzuca, aby gdyby juz zył wonle, zable go przed narodzen1em" /PL 44,423-424\%, por. Decretum Gratian1, C.32, q.2, c. 7 .

17 In IV Sententiarum distinctio 31, vykzad tekstu. 
W orresie Odrodzenia Sykstus $V$ potepia przerymanie clazy

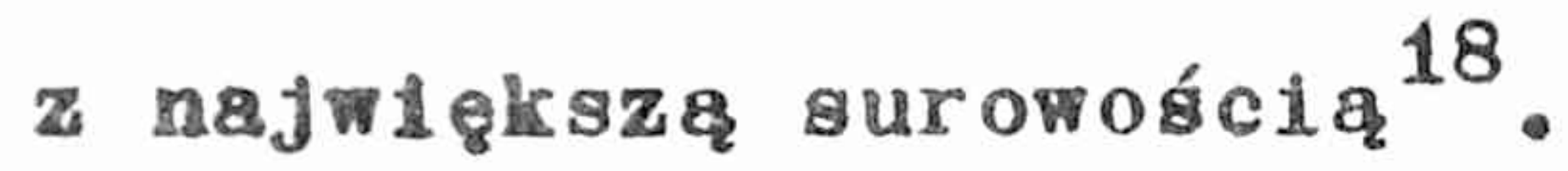

W sto lat później/1679 r./ Innocenty XI odrzuca propozycje pewnych kanonistó sprzyjajacych laksyzmowi, usilujacych usprawied11wíc przerywante ciazy przed czasem, wtórym - wedlug pewnych autorów - dusza laczy się z nowym zyciom ${ }^{19}$.

W naszej epoce ostatni papieze fosili dokladnie te samą nauke. Plus XI odpowiedziaz prost na bardzo powazne zarzuty ${ }^{20}$. P1us XII zdecydowanto odrzuci zamierzone zniszczenle płodu, to mianowicie, które ma charakter celu lub środka do celu21. Jan XXIII odwolał się do Urzędu Nauczycielskiego Swletych Ojców, gdy z mocą opowiedziat ale za sakralnym charakterem ludzklego zycia, zwłaszcza, ze "od poczatku potrzebuje ono dzlałania Boga Stworzycielan22.

N1edawny Sobór Powszechny Watykańsk1 II, któremu przemodn1czyl Pawe VI, Jak najsurowiej potępiz spedzanie płodu: "Nalezy พ1ęc z najwięssza troska ochraniać zycie od samego jego poczęcia, spędzanle płodu jak i dzleciobójstwo saz okropnymi przestęstwamin23. Równiez Pawel VI, który dość często na ten temat przemawiał, nie zawahai sie stwierdzić, ze tego rodzaju nauka Kościoła "nie została zmieniona 1 nie moze nigdy ulec zmianie" 24 .

18 Constitutio "Eferaenatam" /anno 1588/, Bullarium Romanum V, 1, 25-27 lub: Fontes Iur1s Canon1c1 I, n.165, s..308-311.

19 Propositiones LKV damatae in Decretis S.0peicil $\mathrm{nr}$ 34, H:Denzinger - A.Schønmetzer, Enchiridion Symbolorum, Freiburg 1967, 2134/1184/: "Llcet procurare abortum ante animationem foetus, no puella deprehensa gravida occidatur aut infametur"; por. P1us IX, Constitutio "Apostolicae Sedis", ASS 5/1869/ 287-312, 312, lub: Fontes luris Canonici III, n.552, ss.24-31.

20 Cast1 connub11, AAS 22/1930/562-565.

21 Fypowiedzi. PIusa XII na ten temat sa liozne, np. Allocutio ad Sodalitatem Medicorum Italorum a S.Luca die 12 Novembris 1944 anno habita, Discorsi e Radiomessag1, t.6, Roma 1944, 191: "Dopók1 człowiek jest niewinny, to jego zycie jest nietykalne, 1 niedopuszczalny jest zaden czyn zmlerzający bezpośrednio do jego zniszczenla, czy to tego rodzaju zniszczenie jest zamierzone jako cel, czy jako środek do celu, czy to chodzi o zycie embrionalne, czy tez w swym pełnym rozwoju osiągnęło juz swojkres", por. wyzej nota.

22 Mater et Magistra, AAS 53/1961/447.

23 Gaudium et spes 51, AAS 58/1966/1072; por. tamze 27, s.1407.

24 Allocutio ad italicos Iuris peritos catholicos qui XXIII Conven- 
8. Poszanowanle zycla ludzklego narzuca sie nle tylko chrześm c1janom. Tego bowiem domaga sie róntez sam rozum ludzki, gdy docloka, czym jest osoba Iudzka 1 czym byé powinna. Czlowiek jako natura rozumna jest podmiotem osobowym zdolnym do rePloksj 1 nad samym soba. Jak rómiez nad wasnymi czynami, a więc jest równiez wolny 1 moze decydować o swolm losie. Wonsekwoncji jest panem sleble, albo ram czej moze takim sie stac, poniewaź doskonali sie wasie i car na swe uslugi odpowiednle ku temu srodk1; na tym waścimie polega jego zadan1e. Jego dusza bezpósednlo stworzona przez Boga jest niematerialna, a więc nlésmiertelna. Dlatego otwiera się na Boga i jedynie Nim znajduje pelną doskonazoś. Źyje jodnak w 1 w 1 spokecrnej z Innym1 ludźm 1 niejako karmi sle wajemnym osoblstym obcowanlem z niml wleodzownym środowisku spolecznym. Zachowujac to, co nalezy sie spoleczeństwu l innym ludziom, każa osoba prawo do bycia sobą, jak równiez do zycia 1 różnych dóbr. Jest to wymogiem ácisłej sprawledliwości, nałozonym wobec niej na wszystik ch.

9. Jednakze zycie doczesne nle zawiera pyatkiego oo należy do osoby. Zwłaszcza, ze ona ma wasny, myzszy pozlom zycia, któro n1e ma kresu. Zycie cielesne należy uznać za podstawowe dobro - warunek w8zystk1ch pozostałych dóbr na ziemi. A przeciez sa wyzsze dobra, dla których będzie wolno, owszem moze być nawet konieczne złozente ofiary z tego zycla. W spoleczeństwie ludzkim dobro wspólne jest colem, któremu poszczególne osoby powinny słuzyć i podporz̧̨dkowac wasne dobra. Nie jest ono jednak dobrem najwyzszym osoby, z tego wględu waśnie obowiąziem społeczeńtwa jest szużente osob1e, pontewaz ona moze osiagnąć przeznaczony soble najwyżzy col tylkow Bogu. Ona tez jedynie Bogu ostatecznle jest poddana. Dlatego nigdy nie będzie moźna uwaźać człowleka za zwykłe narzędz1e, vtórym ktos mógłby dowolnie posługiwać slę dla osiagnięcla wyzszego celu. 10. Jesli chodzi o wajemne prawa 1 obowiazki osoby 1 spoleczeństwa, to do dzledziny moralności naleźy ośiecente sumier, a do prawa okreslanie 1 porząkowante obowi zzkó. Istnieje jednak cały

tu1, eorum favente Societate hab1to interfuerunt /9 XII 1972/, AAS 64/1972/ 776-779. 
szereg praw, których ludzka społeczność nle moze sama przez sį́ nadawad, szczególnłe zaś te, które jako niezależne od niej są wcześnlejsze, a które powinna zabezpieczyć i uczynić skutecznymi. Sa to najezęściej te prawa, które dzisiaj nazywa się "prawami czlowieka", a z których wyraźnego sormułowania chlubi się nasza epoka.

11. Pierwszym prawem osoby ludzkiej jest prawo do žycia. Ma ona wprawdzie 1 inne dobra, z których pewne są cenniejsze, a jednak pramo do zycia jest warunkiem 1 podstawa dla pozostałych. Dlatego nalezy strzec go bardziej niz innych. An1 do społeczeństwa, ani do wadzy publicznej, niezaleźnie od jej formy, w zaden sposob nie nalezy rezerwowanie tego prawa dla jednych a zawieszanie go dla drug1ch. Wszelka dyskryminacja tego rodzaju - dokonana czy to wie rasy czy pici, czy tez w imle koloru skóry czy religil - jest zawgze niegodziwa. To bowiem prawo nie wypływa z czyjegoś uznania lècz je poprzedza, domaga się aprobaty, zaprzeczając mu zaś, narusza się scisła sprawiedliwość.

12. Jeśli powodu do dyskryminacjl zycta ludzkiego upatruje s1e róznych jego okresach, to jest on na równi z innym1 pozbawony słuszności. Prawo do zycla w całości przysługuje nawet najbardziej uposledzonemu starcowi, nie traci go ten, kto cierpi na nieuleczalna chorobe, tak samo pozostaje wocy dla dziecka dopiero co zrodzonego, jak i dla człowieka dojrzałego. Niewatpliwie wszelkie zycle ludzkie domaga sie poszanowania juz od momentu poczecia. Skoro tylko jajeczko ulega zapłodnieniu, rozpoczyna się zyc1e, które nie należy juz ani do ojea, ant do matki ale do nowej, zyjącej istoty ludzkiej, która rozwija się dla sieble samej. I nigdy nie stanie sie ludzka, jeśli juz wedy nia nie była.

13. Najnowsza genetyka bardzo jasno potwierdza to wszystko, co zamaze było oczywiste, niezaleznie od dyskusji nad momentem animacj1 $^{25}$. Tykazała mianowicie, ze lstota zyjaca ma juz od pierwszej

25 Deklaracja ta śwladomie nie podkreśla kwestil momentu animacji. Nie ma co do tego jednogłośnej tradycj1 1 autorzy współcześni jeszcze róznta sie między soba. Jednt mianowicie twierdza, zé to mystepuje wierwszym akresie zycia, drudzy, ze wtedy dopiero, gdy zarodek zatrzyma sie we waściwym mlejscu. Niewatpliwie nie dọ nauki należy rozstrzygnięcie tych kwestii, poniewaź zagadnienie duszy nieśmiertelnej pykracza poza jej zakres. To jest wlaścíle dyskusja fllozoflczna, od której nasza moralna aflrmacja pozostaje niezalezna z dwóch względów: 1/ jeśli nawet utrzy- 
chw1li stała strukture, czyli kod genetyczny: jest człowiekiem, 1 to człowieklem niepodzielnym, jako jednostka, wposazonym we wszystkie plaściwe sobie cechy. Od momentu zapłodnienta rozpoczyna sią cudowny bieg każdego źycia człowieka, którego jednak wszystkie wielkie zdolności myagają czasu na waściwe uporządkowanie 1 przygotowanie do działania.

Moźna stwierdzić co najmniej, że współczesna nauka, nawet najbardziej zaawansowana, nie daje zadnego istotnego oparcia dla zwolonników spędzania płodu. Zreszta nie do biologicznych nauk naleźy wydawante decydujacego orzeczenia o scisle filozoficznych 1 moralnych zagadnieniach, a tego rodzaju jest zagadnienie o momencie, - kt6rym powstaje osoba ludzka jub o prawnej dopuszczalności przerywania ciaży. Z moralnego zaś stanowiska wiadomo - choćby przypadk1em ktoś wątpił, czy skutkiem poczecia jest juz osoba ludzka - ze samo náwet narazante się na nlebezpieczeństwo popełnienia zabójstwa jest oblektywnie grzechem cięzkim. "Człowiekiem jest 1 ten, kío ma nim byćn 26 .

VII. JAN PAWEL II - "FAMILIARIS CONSORTIOn"27

28. Bóg, stwarzając męzczyznę 1 kobietę na obraz swój 1 podobleństwo, wieńczy 1 doprowadza do doskonałości dzleło swych rąk - powołuje ich do szczególnego uczestnictwa w swej miłośc1, a zarazem w swojej mocy Stwórcy 1 ojca poprzez ich wolną 1 odpowiedzialną mspózprace w przekazywantu zycia ludzkiego: "Bóg im błogosławił, mówiąc do nich: "Bądźcie płodni 1 rozmnazajcie się, abyście zaludnili ziemię 1 uczynili ją sobie poddaną" /Rdz $1,28 /$.

Tak wiec podstawowym zadaniem rodziny jest służba zyciu, urze-

muje sie, ze animacja następuje pó́niej, to mimo tego p płodzie zaczyna sie ludzkie zycie /o którym wiadomo z blologii/, które 1 przygotowuje się 1 wymaga duszy: dzleki niej doskonali sie natura otrzymana od rodziców; $2 /$ jeżel1 zaś tzw. "wlanie dusży" uwaza sie tylko za prawdopodobne/czegos przeciwnego bowiem nie da się nigdy ustalie/, to odebranie zycia jest tym samym co naraźente się na niebezpieczeństwo zabicia czlowieka, ktory jest nie jakby $w$ oczekiwaniu, ale juz obdarzony dusza.

26 Tertullianus, Apologoticum 9,8, CCL 1, 103.

27 Pars II, 28-30, AAS 74/1982/ 114-117, przekład polsk1 0sRom/wya. 
czywistnianie w ciągu dziejów plerwotnego błogasławieństwa Stwórcy: przekazywanla - poprzez rodzenie - obrazu bozego z czlowieka na człowieka/Rdz $5,1-3 /$ 。

Płodność jest owocem 1 znaklem miłości małżeńsk1ej, żywym św 1 adectwem pełnego wajemnego oddawanla sie małzonków: "... prawdziwy szacunek dla miłości małzeńskiej 1 cały sens zycla rodzinnego zmlerzaja do tego, zeby małzonkowie, nle zapominajac pozostałych ceIów małżéstwa, skłonni byll mężnle współdzlałać z miłościa Stwórcy 1 Zbawiciela, który przez nich wclaź powiększa 1 wzbogaca swoją ro$d z 1 n e^{28}$

Plodność miłości małżéskiej nie zacieśnia sie wszakże tylko do plzycznego rodzenia dzieci, chocby nawet była pojmowana w swym specyflcznie ludzkim wymiarze: poszerza się 1 ubogaca wszelkimi owo cami życia moralnego, duchowego 1 nadprzyrodzonego, jak le ojciec 1 matka z racji gwego powolania winni przekazać w darze dzieciom, a poprzez dzieci Kościołowi 1 światu.

29. Waínie dlatego, że miłość małzonków jest szczególnym uczestnictwem w tajemnicy zycia i milości samego Boga, Kościół ma świadomość, ze otrzymał specjalne posłannictwo strzeżenia i ochranlanta tak wielkiej godnośc1 małzeństwa i tak wielkiej odpowiedzialnośi za przekazywanie zycia ludzkiego.

Tak więc, w łaczności z nleprzerwaną w ciągu dziejów i żywa tradycją wspólnoty kościelnej, ostatni Sobór Watykański II 1 nauczanie mojego Poprzednika, paṕleża Pawła VI, wyrażone przede wszystkim wncyklice "Humanae vitae", przekazały naszym czasom prawaziwie profetyczne wypowiedzi, które potwierdzaja 1 jasno przedkładaja prastarą 1 wciáz nowa nauke 1 przepisy Kościoła dotyczące małżenstwa 1 przekazywanta źycia ludzkiego.

Dlatego na ostatnim zgromadzeniu ofcowle Synodu wyraźnie oświadczy 11: "Ten Ŝwięty Synod, złaczony w Jedności wiary z Następca sw. Piotra, utrzymuje mocy to, co jest zawarte w dokumentach Soboru Watykańsklego II, a następnie w Encyklice "Humanae vitae", w szczególności to, ze miłość małzeńska winna być w pełni ludzka, wyłączna

pol./ 1981, $\mathrm{nr} 11, \mathrm{~s} .10-11$.

28 Gaudium et spes 50. 
1 otwarta na nowe zyc10 29.

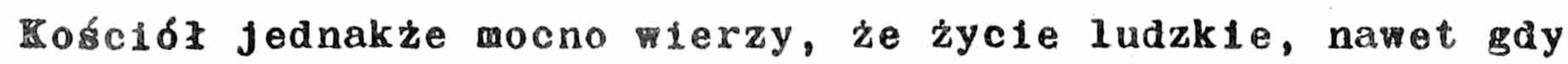
słabe 1 cierpiace, jest zawsze mspaniałym darem Bozej dobroci. Przec1w pesymizmowi 1 ego1zmowi, zaciemntajacym swiat, Koścí́l opowiada się za zyciem: kazdym życiu ludzkim umle odkryć wspaniazość owego "Tak", owego "Amen", którym Jest sam Chrystus /2 Kor 1,19; Ap 3,14/. Owemu "N1e", które zalewa 1 gnębi swiat, przeciwstawla to zyjące "Tak", bronląc $w$ ten sposób czlowieka 1 swiat przed tym1, którzy czyhają na życie 1 zadaja mu smierć.

Kośció jest powolany do tego, aby wzystkim ukazać na nowo, z coraz więszym przekonanlem, swoją wolę rozwijania wszelkimi środkam1 zycia ludzklego 1 bronienta go przeciw jakimkolwiek zasadzkom, niezaleznie od stanu i stadium rozwoju, w którym się ono znajduje. Dlatego Kościót potępla, jako clęźa obrazę godności ludzkiej 1 sprawiedliwości, wszystk1e te poczynania rzadów czy lnnych organów wadzy, które zmierzają do ograntczania jak1kolwiek sposób wolności małzonków wodejmowaniu decyzjl co do potomstwa. Stąd tez wszelki nacisk wywlerany przez te wadze na rzecz stosowanla środków antykoncopcyjnych, a nawet sterylizacj1 1 spęcizania płodu, winten być bezwględnie potęplony 1 zdecydowante odrzucony. Podobnie nalezy napletnowac jako wielce niesprawiedliwy ten rakt, ze w stosunkach międzynarodowych pomoc gospodarcza udzielana na rzecz rozwoju ladow jest uzaleźniona od programów antykoncepcji, steryl1zacji czy spędzania płodu 30 .

\section{JAN PAWEL II - PRZEMOWIENIA}

1. Katecheza podczas audiencjl ogólnej

Kazdy przyzna, ze tym istotnym wymiarem zycia ludzkiego jest rodzina. A rodzinte - prokreacja, gdy poczyna sie 1 rodzi nowy człowlek, przez comęźzyzna i kobieta, jako mazż i żona, stajaz się ojcem 1 matka, rodzicam1, zyskując nową godność 1 podejmując nowe

29 Propositio 21.

30 Orędzie VI Synodu Biskupów 5, Osllom/wyd.pol./ 1980, nr 10, s.3. 
obowiazk1. Znaczenie tych podstamowych obowiazkow jest - z wielu mględów - ogromne. Jest ogromne nie tylko z punktu widzenia tej konkretnej sólnoty, jaka jest 1 ch rodzina, ale także z punktu widzenia mszelkiej wspólnoty ludzkiej, kaźdej społeczności: narodu państwa, szkoły, grupy zawodowej, srodowiska. Wszystko zalezy głównie od tego, jak rodzice i rodzina wypezniaja swe pierwsze 1 podstawowe obowiazki, od tego, w Jaki sposób i w jakiej mierze nauczq być człowiekiem to stworzenie, które dziǫi nim stało sié 1stotá ludzka, otrzymało człowieczeństwo. Rodzina jest w tym niezastąpiona. I trzeba robic wszystko, żeby nie była zastępowana w swej rol1. Wymaga tego nie tylko prywatne dobro każej osoby, ale takze dobro wapólno kazdej społeczności, narodu, państwa na kazdym kontynencie. Rodzina jest wamym centrum wspólnego dobra w jogo róźnych wymlarach waśnie dlatego, ze wiej poczyna się 1 rodzi nowy czlowiek. Nalezy uczynić wszystko, co mozliwe, zeby ta lstota ludzka była juz od samego początku chciana i oczekiwana, przeżywana jako wartośc szczególna, jedyna 1 niepowtarzalna. Powinna ona odczuwać, że jest kimś waźnym 1 pozytecznym, k1ms drogim 1 ogromnie cennym, nawet gdy jest bezsilna jeszcze lub małoletnia, co więcej - waśnie dlatego jest kimś jeszcze bardziej drogim. ...

Pozw6lcie, ze odwołam się do logiki wiary 1 do logiki konsekwentnego humanizmu. To, o czym tu mówie, jest wielkim wołaniem, jest stałym wyzwantem rzuconym kazdemu i wszystkim, specjalnie moze waszych czasach, kiedy matka oczekujaca potomstwa staje czesto w ob$11 \mathrm{czu}$ wielkiej próby moralnej. Istotnie bowiem to, co nazywa sie eufemistycznie "przerwaniem ciąży"/porontentem/, nie może byé oceniane naprawde po ludzku inaczej niż wategoriach prawa moralnego, czyl1 sumienia. Mógłbym wiele, wiele mówić o tym, gdyby nie wyznania w konresjonałach 1 na pewno w poradniach świadomego macierzyństwa.

A zatem nie wolno zostawiac przyszłej matki samej z jej watpliwościami, trudnościami 1 pokusami. Powinniśmy byé przy niej, zeby starczyło jej odwagi 1 ufności, żeby nte obclążyła swego sumienta, zeby nie została naruszona nafbardziej poddtawowa więź szacunku człowieka dla czlowieka. Albowiem taka wié powstaje womencie poczęcia. Dlatego wszyscy powinniśmy $w$ pewnym sensie być z kaźda matką spodziowajaca się potomstwa 1 powinní́my ofiarować jej wszelka mozilwa po$\operatorname{moc}^{31}$. 
2. Homilia podczas Mszy ś. na Capitol Mall waszyngtonie 32

Nie zawaham sie głosić wobec was 1 wobec śriata, ze każde zycie ludzkie - od momentu jego poczęcia 1 poprzez wszystkie kolejne etapy - jest swięte, poniewaz życie ludzkie stworzone zostało na obraz 1 podobieństwo Boga. Nic nie przemyzsza wielkiej godności osoby ludzk1ej. Zycie ludzkie nie jest jakąś 1deą czy abstrakcją; zycie ludzkie jest konkretną rzeczywistością istoty, która zyje, która działa, która rośnie 1 rozwija się; zycie ludzkie jest konkretną rzeczywistościa istoty, która jest zdolna do milości 1 do szuzenia ludziom.

Pozwólcle, ze powtórzę to, co powiedzlałem podczas ostatnloj pielgrzymk1 do mojej ojczyzny: "Jesll sie narusza prawo czlowieka do zycia tym momencie, w kórym on poczyna się, on jako czlowiek, pod sercem matki, godzi się pośrednto w cały lad moralny, który słuzy zabezpieczeniu nienaruszalnych dóbr człorieka. zycie jest pler szym wóród tych dóbr. Kościóz broni prawa do życia nle tylko z uwagi na majestat stwórcy, który jest tego zycia pierwazym Dascá, ale rómnoczésnie ze mzględu na podstawowe dobro człowiekam33.

Zycie ludzkie jest bezcenne, poniewaz jest darem Boga, zutórego miłośc jest nieskończona; a kledy Bóg daje zycie, daje je na zawszo. Zycle ludzkie jest bezcenne takze dlatego, ze jest myrazem 1 omocem miłośc1. Dlatego zycie powinno wyrastac zonie malsenstoma 1 alatogo małżenstwo 1 wzajemna miłość rodzlców winna cechowaś welkodusznośc dawaniu sie sobie nawajem. Wlelkie nlebazpleczexstwo dia zycia rodzinnego - łonie każdego społeczeństwa, któreģo bozkam sá przyjemnoś, wygoda 1 niezależność - polega na tym, ze ludzle zamykaja wasne serca 1 staja sie samolubni. Lek przed ustawicznynd poáwięcentami moźe przerodzlé majemna miłośc męza l żony

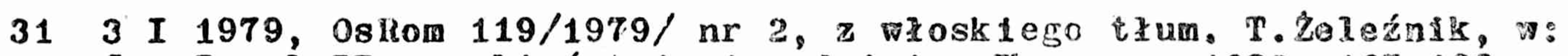
Jan Pawei II o małzeństwie 1 rodzlnle, Warszawa 1983, 105-106.

$327 \times 1979$, AAS 71/1979/1271-1273, z angielskiggo tum.JoJarea, w: Jan Pawez II o małzeństwie 1 rodzinge, dz.cyt., 122-123; por. Allocut10 ad obstëtrices//26 I 1980/, AAS 72/1980/ 84-98, przeklad polsk1 os Rom/wyd.pol./ 1980, nr 3, s.3.

33 Nowy Targ, 8 VI 1979. 
łości samych siebie - dwie miłości istniejizce obok siebie, zanim sie rozłączą. …

5. Aby małzeństwo chrześcijańskie mogło sprzyjać pełneillu dobru 1 rozwojowi pary małżéskiej, musi siź inspirować Ewangelia, a zatem musi być otwarte na nowe życie - nowe życie, które ma być dawane 1 przyjmowane z wielkodusznościa. Małżonkowie są także powołani do stworzenia atmosfery rodzinnej, w której dzieci mogłyby być szczęśliwe, oraz do prowadzenia pełnego $i$ wartościoweg̉ życia ludzkiego 1 chrześcijańskiego.

Madość w rodzinie wymaga wiele zarówno od rodziców, jak 1 od dzleci. Kaźdy członek rodziny $w$ szczególny sposób musi stać się sługa Innych 1 dzielí́ z nimi ich ciężary/Gal 6,2; Flp 2,2/. Kaźdy musi wykazać zainteresowanie nie tylko swym własnym życiem, lecz takze życiem innych członków rodziny: ich potrzebami, ich nadziejam1, 1ch 1deałami. Decyzji co do liczby dzleci 1 wymaganych pośrięceń dla nich nie można podejmować mając na uwadze tylko zwiększanie własnych wygód 1 zapewnianie sobie spokojnej egzystencj1. Zastanawiając się nad tą sprawa $*$ obliczu Boga, przy pomocy lask płynących z sakramentu, rodzice kierowant nauczaniem Kościoła powinni pamiętać, ze mniej waźne jest pozbawienie $1 \mathrm{ch}$ dzieci pewnych wygód czy korzyści materialnych anizeli pozbawiente ich obecności braci 1 sióstr, którzy by $1 \mathrm{~m}$ pomagali wzrastać $w$ człowieczeństwie i doznawać piękna życia we wszystkich jego okresach 1 w całej jego róznorodności.

Jeśli rodzice całkowicie spełnia wymogi 1 mozliwości, jakie niesie z sobą ten wielki sakrament, będą mogli dołączyć się do Maryjnego hymnu do Twórcy życia - do Boga, który uczynił z nich swych wybranych współpracowników.

6. Człowiek musi cení każdą osobę, która jest niepowtarzalnym stworzentem Bozym, wezwanym, aby być bratem lub siostra Chrystusa na mocy Wcielenta 1 powszechnego Odkupienia. Na tych przesłankach opiera się dla nas świętość źycia. I na tych samych przesłankach opiera się nasza cześ́ wobec zycia - kazdego zycia ludzkiego. To tłumaczy nasze wysiłki obronte zycia ludzkiego przed Jakimkolwiek wpływem czy działalnością, które mu zagraźają lub je osłabiaja, Jak teź nasze vysiłki, aby uczynić kaźde zycie bardziej ludzkim we mszystkich jego aspektach.

Będziemy więc zawsze stawac w obronie, kiedy zycie ludzkie be- 
dzie zagrozone. Kiedy będzle atakowana świętość zycia przed narodzentem, będziemy się temu przecimstaniać 1 głosić, ze nikt nie ma wadzy niszczenia nie narodzonego życia. Kiedy będzie się traktowac dz1ecko jako cizzar lub patrzeć na nie jedynie jako na środek do zaspokojenta potrzeb emocjonalnych, będziemy sie temu przectwstawaé 1 przypominac, ze każe dziecko jest jedynym 1 niepowtarzalnym darem Boga, 1 ma prawo do kochającej 1 zjednoczonej rodziny. 